\title{
Dual functions of Expansin in cell wall extension and compression during cotton fiber development
}

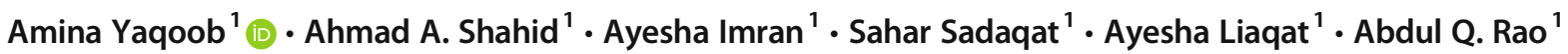

Received: 5 January 2020 / Accepted: 7 May 2020 / Published online: 25 May 2020

(C) Institute of Molecular Biology, Slovak Academy of Sciences 2020

\begin{abstract}
Cotton fiber provides a distinct picture of cell wall synthesis. It is an epidermal single-cell extension of Cotton plant seed and undergoes three main stages of development, (1) initiation, (2) elongation and (3) maturation. The fiber initiation characterized by thin primary cell wall formation, which is extended afterward by the action of specific non-enzymatic proteins called Expansins, which promote expansion between cellulose microfibrils by cutting the bridges between cellulose and Hemicellulose residues. The elongation phase followed by a compression phase where the secondary cell wall becomes compact and thickened by the deposition of polysaccharides. The fiber development eventually ends up in the maturation phase, attaining the final maximum length of $\sim 2.5-3.0 \mathrm{~cm}$. However, the most critical periods of Cotton fiber development are cell wall extension and cellulose deposition. Many studies have focused on the role of Expansins in cell wall elongation, but the significance of expansins in cellulose deposition of the secondary cell wall has barely studied to date. This paper, therefore, is a brief review, which will emphasize the role of Expansin in both cell wall extensibility and polysaccharide deposition during the compression phase. However, the versatile role of Expansin proteins in cellulose deposition and cell wall elongation need a more critical experimental approach.
\end{abstract}

Keywords Cotton $\cdot$ Fiber $\cdot$ Cellulose $\cdot$ Cell wall $\cdot$ Expansin $\cdot$ Extension $\cdot$ Compression

$\begin{array}{ll}\text { Abbreviations } \\ \text { CW } & \text { Cell wall } \\ \text { PM } & \text { Plasma membrane } \\ \text { XyG } & \text { Xyloglucans } \\ \text { ER } & \text { Endoplasmic reticulum } \\ \text { SCW } & \text { secondary cell wall } \\ \text { DPA } & \text { Days post anthesis } \\ \text { CFML } & \text { cotton fiber middle lamella } \\ \text { SEM } & \text { Scanning electron microscope } \\ \text { CMs } & \text { cellulose microfibrils } \\ \text { Gh } & \text { Gossypium hirsutum } \\ \text { DPBB } & \text { double-psi beta-barrel } \\ \text { CBM63 } & \text { C-terminal } \beta \text {-sandwich }\end{array}$

Amina Yaqoob

aminayaqoob13@gmail.com

1 Centre of Excellence in Molecular Biology, University of the Punjab, 87-West Canal Bank Road, Lahore 53700, Pakistan

\section{Plant cell wall, structure and composition}

To understand Cotton fiber development, it is necessary to have a brief knowledge of plant cell walls at first. The plant cell wall gives a specific cell shape, serving as an interface between neighboring cells and intercellular communication (Cosgrove 2015a). The cell wall consists of primary and secondary walls, where the primary wall meant for developing daughter cells, which are proficient for more growth while a secondary wall is a thick mature boundary for specialized cells with impregnation of lignin (Xi et al. 2017). The cell wall is majorly composed of cellulose and proteins along with chitin, cutin, lignin, and several electrolytes as its structural components. Chitin is a polymer of glucosamine and specifically present in some cell walls. Cellulose is a polymer of glucose featured with Micelle, Microfibril and microfibrils arrangements (Fry 2018). A bundle of nearly 100 cellulose chains gives rise to an elementary fibril structure called a micelle. The parallel arrangement of 18-22 micelles, along with hydrogen bonding interactions, results in another structure called crystalline microfibril. The 
microfibrils together contribute to form a compact microfibril (Khalil et al. 2015). Additionally, different types of matrix polysaccharides are also present in cell walls with the same $\beta$-1,4-linkage. Hemicellulose, xyloglucans, xylans, glucomannans and mixed linkage glucans grouped as hemicelluloses. Pectic polysaccharides, such as Rhamnogalacturonan I, II, Glucuronic acid, Galacturonic acid, and homogalacturonan, are more abundant during primary cell wall development where they undergo the interactions with various cell wall molecules to strengthen up the architecture (Cosgrove 2018; Heinze 2015). A model of the cell wall architecture that contains three networks have been proposed to date which explains the cell wall assembly and packing of molecules (Meents et al. 2018) (Fig. 1). The three-network model constitutes (a) cellulose-xylan, (b) pectin-calcium (c) protein-phenolic arrangements which collectively participate in building up the cell wall skeleton.

\section{Cellulose-Xylan sandwich}

The previously reported cell wall model showed that cellulose chains not directly linked with each other; instead, they tied to each other through other polysaccharides. This model is no longer acceptable now and an alternative illustration of cell wall network showed that cellulose microfibrils potentially glued together through a defined single layer of xyloglucans (Cosgrove 2015a, b). The lengths of xyloglucans (XyG) are longer than the spaces between cellulose microfibrils. Therefore, adjacent cellulose microfibrils cross-linked by these long polysaccharides, which tether together the cellulose fibrils by tight surface adhesion (Meents et al. 2018).

\section{Pectin polysaccharide network through calcium bridges}

The polymers of pectin have alternate blocks of branched and unbranched molecules with methyl-esterification and differential esterification respectively. Where non-esterified blocks clump together through Calcium bridges and form zones of junctions to hold the gel consistency (Yang and Wang 2016). A network of calcium and acid gel formed by pectin polysaccharides. Low ester pectins form Calcium-based gels while highly esterified pectins generally made up of sucrose and form acidic gels. The aggregate size of the gel depends on calcium concentration. Low calcium levels in zone comprise of two or three chains with enough calcium ions binding. While high calcium levels result in a large sheet, type aggregate with weaker non-covalent ionic interactions. Therefore, calcium availability greatly affects the gel consistency in cell wall architecture (Somssich et al. 2016).

\section{Network of structural proteins and phenolic compounds}

Crosslinking of phenolic-protein with pectin polymers gives rise to a warp and weft structure, interweave through the above networks. Phenolic compounds are about $2 \%$ of the cell wall constituents while structural proteins make up 2-10\% of cell wall dry mass (Voxeur and Höfte 2016).

\section{Formation of plant cell wall}

A mature plant cell when undergoes cell division, the cell plate is produced by phragmoplast, followed by the expansion
Fig. 1 A proposed cell wall model with three-network architecture. Microfibril-Xylan network presenting Hydrogen bonding and surface adhesion between microfibrils and xylans. Pectin polysaccharide network characterized by Calcium bridges while crosslinking of phenolic compounds and structural proteins by several interactions are showing the third network of proteins bonding. These three networks together constitute the overall building of a cell wall

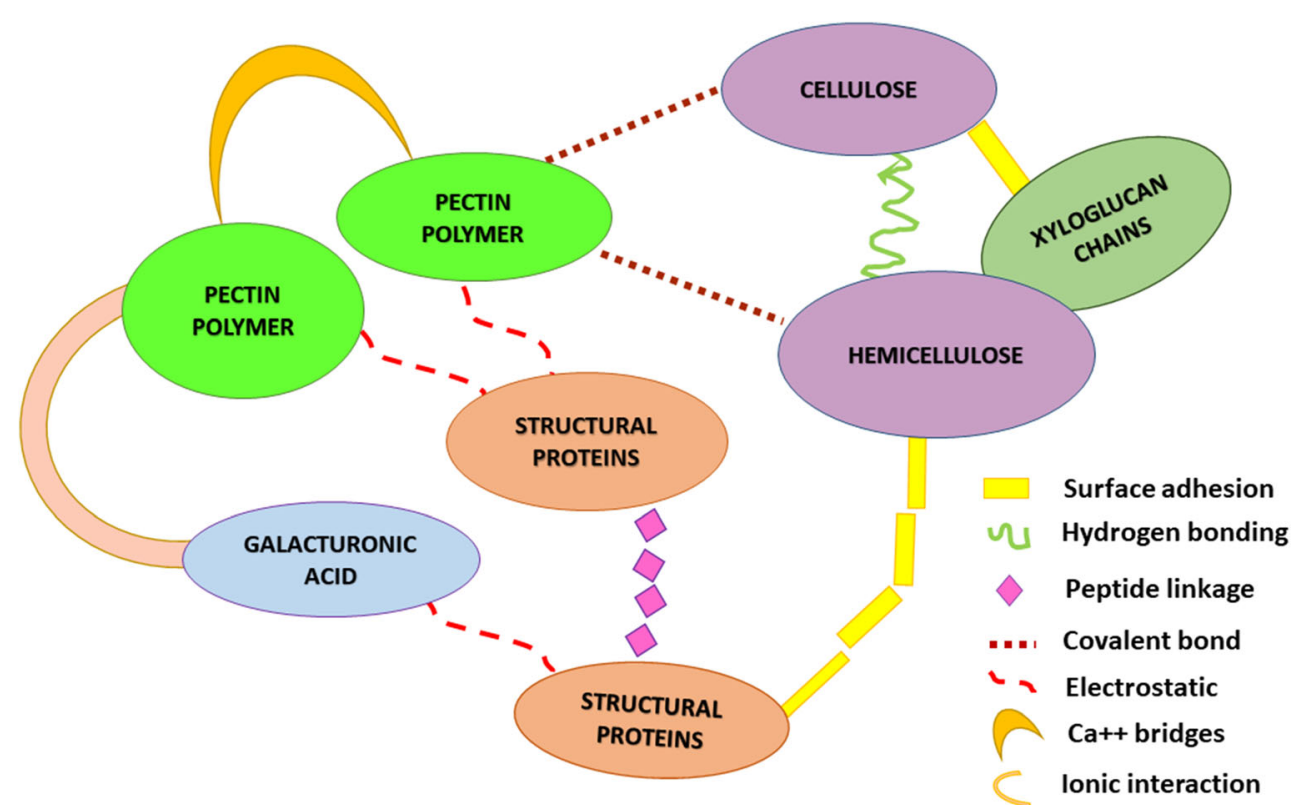


of phragmoplast through microtubule polymerization at leading zone i.e. forefront elongation (Smertenko et al. 2018). Cell plate functions as a precursor to the primary cell wall and originates from the Golgi apparatus. Once the cell plate assemblies, the phragmoplast disassemble. It cuts endoplasmic reticulum (ER) of the parent cell and ER compartments then migrate from periphery to equator (McCann and Knox 2018). ER strands finally arranged in between the expanding vesicles of the Golgi apparatus and give rise to budding plasmodesmata pores. Each pore possesses an ER-derived membranous rod called desmotubule (Zhang et al. 2016). Following the formation of the cell plate and plasmodesmata pores, the development of middle lamella takes place. Cell plate itself deposited lignin, membrane proteins, calcium, and magnesium pectates to become a middle lamella (Buschmann et al. 2016). Fibrils of Cellulose, on both sides of the middle lamella, form the primary cell wall. When a cell is young and small, the cellulosic fibers loosely packed due to the incomplete crosslinking of cellulose fibers (Cosgrove 2018). In the young leaves, the only permeable primary cell wall is present, composed of intricate microfibrils network. Sometimes cutin may also be present along with the primary wall and make it impermeable. Secondary cell wall develops after primary wall formation by deposition of cellulose fibrils. Following this deposition, lignification takes place as a final step in SCW biosynthesis where monolignols secreted by either lignifying cells or neighboring cells. (Buschmann et al. 2016).

\section{Cotton fiber; a fascinating cell wall model}

The plant fibers categorized, based on their position, chemical nature, significance, and application, (Ramamoorthy et al. 2015). Cotton fiber is one of the most significant plant fibers and considered the king of textile industry fibers. Cotton fiber is a thick cellulosic secondary cell wall, surrounded by a thin cuticle of a primary wall (Huang et al. 2016). Certain proteins, polysaccharides, and phenols deposited among the cellulosic cytoskeleton giving the fiber its compactness or strength. Cotton fiber development divided into overlying phases of initiation, elongation, tightening and maturation (as shown in Fig. 2). It starts with the protrusion of epidermal cell wall extensions which become elongated up to $\sim 2.5$ to $3.5 \mathrm{~cm}$ from 5 to 18 days post-anthesis (DPA) (Stiff et al. 2016), followed by a transition stage of deposition of thin intermediary secondary cell wall "twisting" layer (comparable to S1 layer in woody fiber). The transition period enters into the "thickening" phase of the secondary cell wall; a rare characteristic of Cotton fiber only, which commences the deposition of pure cellulose fibrils to make it compact (Rathgeber et al. 2016). A mature Cotton fiber, when harvested, is a thick secondary cell wall with $\sim 200 \mathrm{~nm}$ length, $95 \%$ cellulose content and primary wall cuticle. The cellulose content then raises to $99 \%$ after cleaning and bleaching in the textile industries (Sun et al. 2015). Gossypium barbadense $(\mathrm{Gb})$ produces better quality fiber than that of Gossypium hirsutum (Gh) (Ahmed et al. 2018). Gh fiber possesses the bridges of adhesive cotton fiber middle lamella (CFML) which joins fiber bundles together. CFML, however, not confirmed in other Cotton species (Hernandez-Gomez et al. 2017).

\section{Cotton fiber elongation (5-18 DPA)}

Cell wall elongation of developing Cotton fiber specifically occurs at acidic or low wall $\mathrm{pH}$, which affects the enzyme activation energies. The decrease in cell wall $\mathrm{pH}$ throughout auxin-induced growth triggers glycanases, which attack the components of pectin and xyloglucans (Hernandez-Gomez et al. 2017). As a result, disruption of Pectin-bound calcium ions may occur, but it mildly affects the gel strength. Besides pectin aggregate disruption, degradation of xyloglucans also further loosens up the cell wall integrity. Expansin proteins are another group of cell wall expansion element, which promote the spillage between microfibrils by cutting cellulose and Hemicellulose (McCann and Knox 2018). Several cellular secretions with different chemical natures also found to be involved for greasing effects in wall loosening. Enzymes such as Transglucosylase and hydrolases cut/ligate polysaccharides and cut/ligate hemicellulose/pectin respectively (Marowa et al. 2016). The basic electrolytes secreted during elongation are still under investigation for their exact roles or effects. This segment will present a generalized picture of cell wall expansion (Fig. 3) followed by the tightening of the cell wall.

The architecture of cellulose microfibrils suggests that an increased number of xyloglucan aids in holding the cellulose microfibrils to give the wall a turgid and compact consistency (Marowa et al. 2016). Degradation of xyloglucan molecules causes the cell wall to weaken/loosen. Xyloglucan endotransglucosylase catalyzes the integration of xyloglucan or Xyloglucanase directly hydrolyze the xyloglucan to disrupt its composition for cell wall loosening (Guo et al. 2016). Therefore, the increase and decrease in xyloglucan and associated oligosaccharides dramatically monitor the turgidity and tension in plant cells (Sampedro and Cosgrove 2005). Overexpression of Xyloglucanase in transgenic poplar plants resulted in the primary wall loosening and inhibition of gravitropism in the secondary wall for upright stem elongation (Cosgrove 2016). Another approach reported that the transformation of the cellulase gene for its overexpression in Arabidopsis also resulted in reduced xyloglucan content and eventually increased cell size (Xiao et al. 2016). Likewise, Hemicellulose xyloglucan content, being a tethering molecule for cellulose microfibrils, also plays a significant role in changing the cell size or volume (Cosgrove 2016). Expansins are one of the worth mentioning proteins while discussing the mechanism of cell wall elongation as they mediate acid-induced growth without the lytic activity of wall oligos 

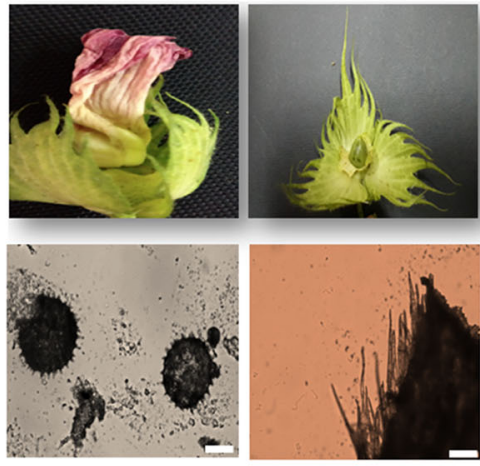

1 DPA

5 DPA
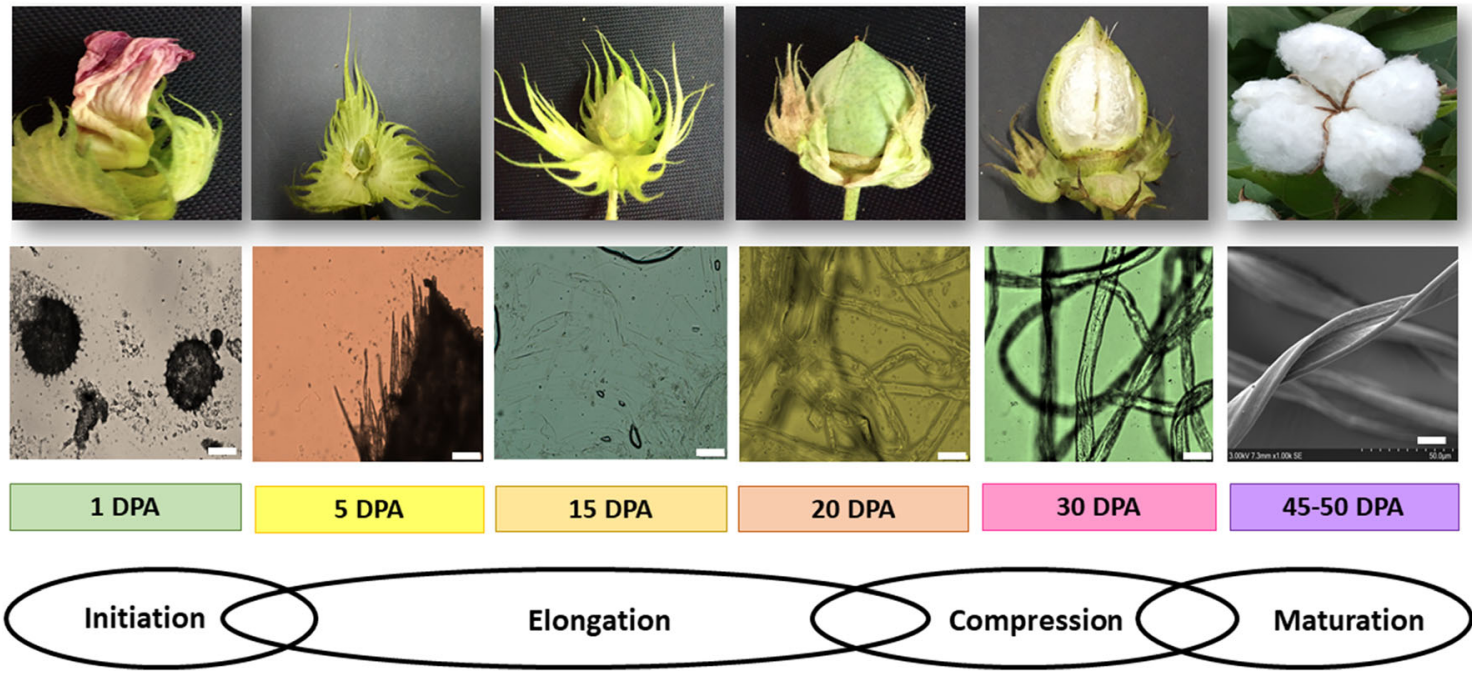

15 DPA

20 DPA

30 DPA

45-50 DPA

Fig. 2 The overlapping stages of Cotton fiber development. The slides were prepared by cutting thin sections of developing bolls at several days post-anthesis (DPA). Images were taken under a bright-field compound microscope at 20X, except mature fiber, which observed at 2000X under Scanning Electron Microscope (SEM). The scale bar is showing $20 \mu \mathrm{m}$ length in bright-field microscope images while $50 \mu \mathrm{m}$ in SEM image. One DPA, tiny extensions of seed epidermal cells are visible. Five DPA,

(Fig. 3). Molecular approaches declared the bifunctional role of expansin in wall loosening when isolated from bacteria. Modern biotechnology applications involve the transformation of expansin gene into plants for enhancing the fiber elongation etc. As overexpression of expansin found to increase the cell wall expansion (Sampedro and Cosgrove 2005).

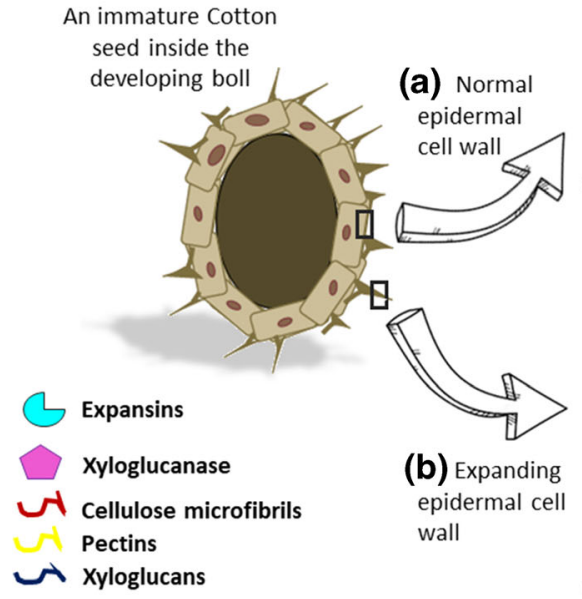

Fig. 3 A plant cell wall (CW) surrounds the plasma membrane (PM) which contains a lipid bilayer with ionic pumps/channels. During the cell wall expansion phase, Auxin facilitates proton pumping into $\mathrm{CW}$ by activating membrane $\mathrm{H}+$-ATPase proton pumps and causes $\mathrm{CW}$ acidification. Expansin proteins activated in an acidic environment and start cleaving the tight packing of cellulose microfibrils $(\mathrm{CMs})$ with

\section{Cotton fiber compression (25-40 DPA)}

An expanded fiber cell wall, when attaining a specific size or length, tightens-up for strengthening and maturation (Williams et al. 2018). For this purpose, various cellular secretions with longer, stickier composition become involved in epidermal outgrowths begin to elongate. Fifteen DPA, The thin section of immature Cotton boll characterized by turgidity and undifferentiated loose fiber smears. Twenty-thirty DPA, developing bolls with thicker fibers are dominant; with the beginning of secondary cell wall deposition i.e. cellulose filling. Forty-five to fifty DPA, Final compact and mature fiber under SEM

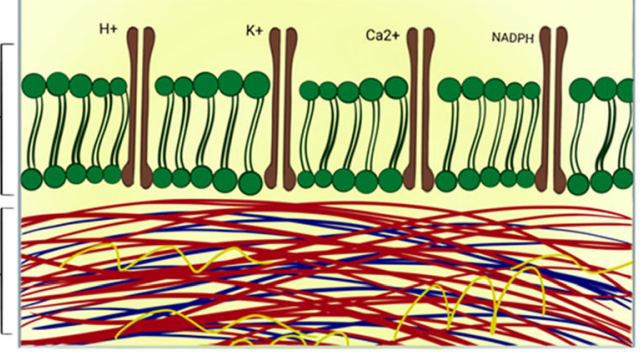

$\mathrm{CW}-$
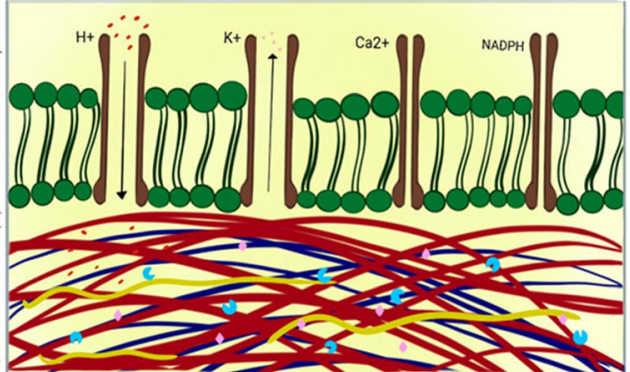

Xyloglucans (XyGs). This cleaving results in loosening/sliding of CMs and expands the $\mathrm{CW}$. Besides, acidic protoplast also activates pumping of potassium ions $(\mathrm{K}+)$ into the cytosol, high concentration of $\mathrm{K}+$ ions results in hypertonic cytosol and stimulates the water intake for tensile strength of plant cell during expansion 
sticking up the polymers together. Pectin methyltransferases catalyze the formation of gel aggregates with pectin polymers (Fry 2018). Both esterified and non-esterified polymers clumped together through Calcium and ionic bridges and give rise to compact consistency. Besides, peroxidases carry out the oxidative crosslinking of phenolics, which formed through the Phenylpropanoid pathway e.g. Glurono-arabinoxylans in the grass, Pectins in some plant families, Lignin, Structural proteins (e.g. HRGPs) and Flavonoids (Ortega 2017). Transglucosylase Ligate short polysaccharides together to make the network stronger. Glycosidase, debranching enzymes, further undergo the checking of polymers, either properly stick together or not. All this undergoing process of cellulose deposition involves various genes, which are responsible for cellulose synthesis by producing all the proteins needed in this process. All the proteins work as a complex in a membrane-localized manner (Cosgrove 2016). The orientation of cellulose deposition during compression strictly monitored and regulated by the protein complex as it plays a key role in cell growth. Different transcription factors have also reported which are involved in regulating the process of cellulose deposition (Little et al. 2018).

\section{Expansin: The unusual proteins of cell wall}

Expansin, the cell wall proteins, firstly discovered in cucumber hypocotyls and reported as cell wall loosening nonenzymatic proteins by McQueen-Mason in 1992 (Cosgrove 2016). Expansins constitute four subfamilies: $\alpha$-expansin, $\beta$ expansin, expansin-like A and expansin-like B. These are involved in an irreversible cell wall extensibility and naturally exist in all plants. Even some of the microbes and small organisms like snail also have expansin proteins. Decades after their discovery, the versatile roles of expansin in plants became evident (Marowa et al. 2016). Due to their ability to sliding the wall polymers by decreasing adhesive forces among adjacent polysaccharides, they aid in remodeling of a cell wall, shortly after cytokinesis (Sampedro and Cosgrove 2005). By cleaving the weak hydrogen bonding between $x y-$ lose and cellulose microfibrils under high turgor pressure due to influx of water, expansins increasing volume of the cell wall and indirectly results in deposition of several polysaccharides in the cell wall during compression/tightening phase (Little et al. 2018). The spaces among cellulose microfibrils, created by expansin activity, potentially filled by the deposition of pectins, hemicellulose, phenols, lignins and cellulose (McQueen-Mason and Cosgrove 1994). Therefore, it assumed that the increase in cellulose content takes place during the cell wall compression phase due to overexpression of Expansin genes (Bajwa et al. 2015; McQueen-Mason and Cosgrove 1994). Various studies have shown that overexpression of expansin genes in transgenic plants, resulted in an elongated cell wall with increased cellulose quantity (Table 1).

\section{Role of Expansin in longitudinal growth of cotton fiber}

Cell wall expansion is restricted to a growing dome-shaped apical growth pattern, filled with vesicles and secretory vacuoles. Elongating Cotton fiber cell, however, observed to be following a diffused unidirectional growth. It is evident due to the (1) lack of zones formation in growing cell tip (Ruan 2007) and (2) inhibition of radial cell expansion by the diagonal arrangement of cellulose microfibrils (Saxena and Brown 2005). The Cotton fiber cell, therefore, elongate vertically to the alignment of cellulose tubules, representing a unidirectional growth of cell tip (Heinze 2015). Expansin mediates the Cotton fiber elongation. Plasmodesmata are open for solute transport during the early elongation phase (0-9 DPA), creating a more acidic intracellular environment (Sampedro and Cosgrove 2005). At this point, sucrose utilization in a cell mediated by the Sus gene, and sliding of cellulose microtubules to loosen/expand the cell wall regulated by Expansin genes (Ahmed et al. 2018). By the mid of expansion phase, plasmodesmata became closed with the maximal intake of sugar and ions, generating a high turgor pressure in fiber to maintain the maximum elongation up to 16 DPA. Following elongation is cell wall rigidity phase (19-40 DPA) where plasmodesmata reopened for trafficking of molecules, involved in cellulose deposition between fiber and adjacent epidermis along with the decreased expression of Expansin to stop further elongation (Bajwa et al. 2015; Georgelis et al. 2012; Han and Kim 2016). Besides, actin microfilaments also constitute intracellular support for the trafficking of vesicles in growing cell tip. Silencing of GhACTIN, fiber-specific actin gene, found to reduce the number of vesicles in cell tip along with the inhibition of cell elongation (Yi and Li 2012).

\section{Role of Expansin in cellulose deposition of cotton fiber}

In cotton secondary cell wall (SCW), development orchestrated by the series of changes starting from the deposition of cellulose, hemicelluloses and pectin underneath the primary cell wall (Ahad et al. 2018; Voxeur and Höfte 2016). This complex is permeable and impregnated with thick materials, which make a home for different developing activities. Cellulose microfibrils potentially glued together through a defined single layer of xyloglucans. These contact regions of cellulose-xyloglucans thought to be the specific target sites for both $\alpha$-expansins and bacterial expansins. Where expansins disrupt the polysaccharides to make a room for cellulases at surface glucans of cellulose fibrils (Cosgrove 2014; Georgelis et al. 2012). 
Table 1 A brief presentation of selective research studies regarding genetic modification of Expansin genes for improvement in plant cell wall and cellulose deposition

\begin{tabular}{|c|c|c|c|c|c|c|}
\hline $\begin{array}{l}\text { Sr. } \\
\text { No }\end{array}$ & Gene name & Sub-family & $\begin{array}{l}\text { Experimental } \\
\text { approach }\end{array}$ & Target plant & Effect on cell wall & Cited by \\
\hline 1. & ClEXPA1/ClEXPA2 & $\alpha$-expansin & overexpression & $\begin{array}{l}\text { Tobbacco plant (Petunia } \\
\text { hybrida) }\end{array}$ & $\begin{array}{l}\text { increased amount of cellulose } \\
\text { in stem cell walls }\end{array}$ & (Wang et al. 2011) \\
\hline 3. & AtEXPA18 & $\alpha$-expansin & Overexpression & Rice (Oryza sativa L.) & $\begin{array}{l}\text { Enhanced extension in } \\
\text { epidermal root cell walls }\end{array}$ & $\begin{array}{l}\text { (ZhiMing et al. } \\
\text { 2011) }\end{array}$ \\
\hline 4. & AtEXPA4 & $\alpha$-expansin & $\begin{array}{l}\text { Expression profile } \\
\text { of gene }\end{array}$ & Arabidopsis thaliana & $\begin{array}{l}\text { Found to have a role in cell } \\
\text { wall softening of the stigma }\end{array}$ & (Mollet et al. 2013) \\
\hline 5. & AtEXPLA2 & $\begin{array}{l}\text { Expansin-like } \\
\text { A }\end{array}$ & Genetic mutation & Arabidopsis thaliana & $\begin{array}{l}\text { Change in cell wall } \\
\text { extensibility } \\
\text { resulted in an increased } \\
\text { pathogenic defense }\end{array}$ & $\begin{array}{l}\text { (Abuqamar et al. } \\
\text { 2013) }\end{array}$ \\
\hline 6. & СpEXРАЗ & $\begin{array}{l}\text { Expansin like } \\
\text { A }\end{array}$ & $\begin{array}{l}\text { Gene } \\
\text { overexpression }\end{array}$ & Gossypium hirsutum & $\begin{array}{l}\text { The increased cellulose content } \\
\text { of transgenic fiber }\end{array}$ & (Bajwa et al. 2013) \\
\hline 7. & GmEXPB2 & $\beta$-expansin & $\begin{array}{l}\text { Gene } \\
\text { Overexpression }\end{array}$ & Rice (Oryza sativa L.) & $\begin{array}{l}\text { modified the root cortical cells } \\
\text { for root hair development } \\
\text { through cell wall loosening }\end{array}$ & (Zou et al. 2015) \\
\hline 8. & $\begin{array}{c}\text { VvEXPA14 and } \\
\text { VvEXPA18 }\end{array}$ & $\begin{array}{l}\text { Expansin-like } \\
\text { A }\end{array}$ & Overexpression & Arabidopsis thaliana & $\begin{array}{l}\text { Enhanced cell expansion } \\
\text { during } \\
\text { root elongation }\end{array}$ & (Suzuki et al. 2015) \\
\hline 9. & GhEXPA8 & $\begin{array}{l}\text { Expansin-like } \\
\text { A }\end{array}$ & $\begin{array}{l}\text { Gene } \\
\text { overexpression }\end{array}$ & Gossypium hirsutum & $\begin{array}{l}60 \% \text { improved cellulose } \\
\text { content } \\
\text { of transgenic plants }\end{array}$ & (Bajwa et al. 2015) \\
\hline 10. & AtEXPA10 & $\alpha$-expansin & Overexpression & Tobacco plant & $\begin{array}{l}\text { Enlarged leaf and stem due to } \\
\text { expanded plant cell walls }\end{array}$ & (Kuluev et al. 2016 \\
\hline 11. & ТаEХРВ7-B & $\beta$-expansin & Overexpression & Arabidopsis thaliana & $\begin{array}{l}\text { Modulated cell wall } \\
\text { architecture } \\
\text { against abiotic stress }\end{array}$ & (Feng et al. 2019) \\
\hline 12. & EXPA1 & $\begin{array}{l}\text { Expansin-like } \\
\text { A }\end{array}$ & Knock out gene & Arabidopsis thaliana & $\begin{array}{l}\text { Resulted in defected cell } \\
\text { division } \\
\text { and a radial swelling of the } \\
\text { pericycle during lateral root } \\
\text { formation }\end{array}$ & $\begin{array}{l}\text { (Ramakrishna et al. } \\
\text { 2019) }\end{array}$ \\
\hline
\end{tabular}

Plant expansins, from onion epidermis, when observed through atomic force microscopy, have two major domains at $\mathrm{C}$ and $\mathrm{N}$ terminal. The $\mathrm{C}$-terminal domain involves in cell wall loosening, it binds to cellulose and pectin through different surface molecules at opposite sides (Fig. 4). While the Nterminal domain is a hexamer of double-psi beta-barrel (DPBB) and does not promote cell wall loosening even at higher concentrations, 26 times higher quantities than the full-length proteins which cause wall expansion (Cosgrove 2014; Yennawar et al. 2006). Binding of expansin to cell wall is one of the major hindrances in finding out the expansin binding mechanisms. As sometimes, expansins found to be having such a tight binding with a hypocotyl cell wall that extraction with detergent, $1 \mathrm{M} \mathrm{NaCl}, 1 \mathrm{M}$ urea failed to extrude them (Sampedro et al. 2015). Likewise, a tight EXPB binding to rice cell walls also seen where extraction was not possible until the proteins were denatured (Lee and Choi 2005). Transgenic Arabidopsis with transformed CBM63 fragment showed multiple effects on the cell wall and plant growth i.e. fungal resistance, metabolism and some partially understood mechanics (Cosgrove 2015b). Expansins will not only be able to induce cell expansion in special tissues and organs in vivo but can also act as a potential activator of secondary cell wall formation by directly or indirectly affecting cellulose metabolism in plants (Baccelli et al. 2014; Wang et al. 2011). Synchronization within the plasma membrane along with the Golgi complex is required for cellulose, hemicellulose and lignin deposition during SCW development. There is an elevated concentration of cellulose synthase (sus enzymes) at the plasma membrane to manufacture cellulose microfibrils for SCW development (Ahmed et al. 2018). There are 18-24 fibrils of glucose residues like xylan and mannan found in length and extruded into the matrix of hemicellulose molecules (Wang et al. 2014). The accurate assemblage of plant cell walls during the synchronized activities of cellulose synthase genes and different gene products, organize the cell wall region for the deposition of microfibrils. This interaction plays an important role in cellulose synthesis for 


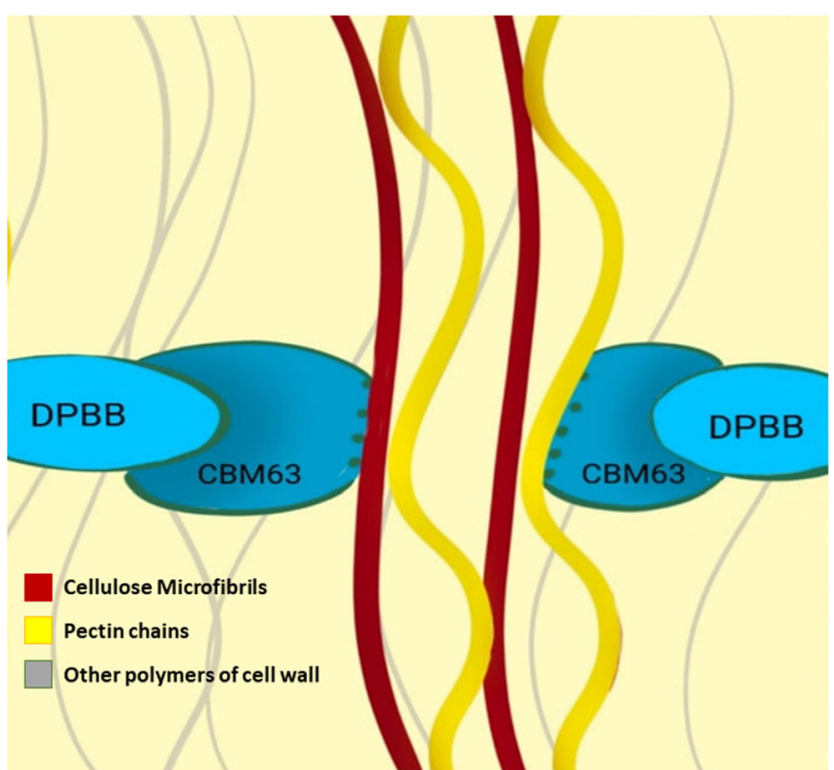

Fig. 4 A proposed model of expansin molecule, possessing two major domains of CBM63 and DPBB. Where CBM63 binds to cellulose and pectin polymers through surface binding molecules. It has hypothesized that this binding enables the expansin molecules to separate the cellulose and pectin polymers, by either sliding them over each other or cleaving them apart

cell wall maturation (Zenoni et al. 2011). All the expansins discovered so far showed paper weakening and cellulose disruption activities but a clear lytic activity has not detected yet. It provides evidence that expansins must undergo a disturbance/rearrangement of cellulose microfibrils without any hydrolytic cleavage. Down-regulation of the expansin gene, PhEXP1, in Petunia hybrid plants resulted in the reduced amount of crystalline cellulose in the cell walls of petal limbs (Wang et al. 2011).

The mutation in the OsEXPB2 expansin gene found to be directly affecting the root system by inhibiting cell expansion. Reduction in the cell length of roots provides essential information on the cellular basis for expansin-mediated plant root system growth (Abuqamar et al. 2013). There are several results indicated that the overexpression of the expansin gene in plants may increase the cellulose content in cell walls. It has hypothesized those expansin proteins could act as a biocatalyst, a cell wall loosening agent or an activator to accelerate accurate cell wall assembly. Interestingly, studies have also revealed that the cellulose contents of the 35Spro: CIEXPA1 and 35Spro: ClEXPA2 cassette in transgenic cotton plants increased by approximately $50 \%$ and $30 \%$ on average, respectively, when compared with that of the wild type. However, the increase in stem height and diameter of the CIEXPA1 and CIEXPA2 overexpression did not produce a significant difference (Zou et al. 2015). Although, expansins related studies support the expansin role in secondary cell wall formation, yet the mechanisms behind still need to be a subject of more study (Cosgrove 2015b).

\section{Concluding perspective}

The term 'wall extensibility' depicts the ability of a cell wall to increase in surface area irreversibly. Since the cell wall expansion is irretrievable, hence more polymers deposited after the elongation phase to give the fiber its final compactness. Unlike bacterial cell wall growth where an increase in wall surface directly couples with the addition of new wall components, plant cell grows in surface area, by a spreading movement of cellulose microfibrils and associated matrix components in the plane of the wall. Expansins are not only playing a role to promote plant cell wall elongation but also imparting an indirect effect for extra cellulose deposition in Cotton fiber. However, the relationship of expansin-cellulose deposition has poorly demonstrated up until now and needs deeper investigations.

Author's contribution 1) AY and AAS designed the main idea of present study, did microscopy and contribute equally in writing the manuscript

2) AI contributed by collecting data from more than 50 research papers

3) SS contributed by drawing all the figures using online drawing tools

4) AL contributed by illustrating tables and reviewed for English Grammar

5) AQR reviewed and finally approved the manuscript

\section{Compliance with ethical standards}

Conflict of interest Authors declare no conflict of interest in submission and publication of this manuscript.

\section{References}

Abuqamar S, Ajeb S, Sham A, Enan MR, Iratni R (2013) A mutation in the expansin-like a 2 gene enhances resistance to necrotrophic fungi and hypersensitivity to abiotic stress in a rabidopsis thaliana. Mol Plant Pathol 14:813-827. https://doi.org/10.1111/mpp.12049

Ahad A et al (2018) Multidimensional roles of flavonoids in background of Gossypium hirsutum. Cogent Food \& Agriculture 4(1):1510754. https://doi.org/10.1080/23311932.2018.1510754

Ahmed $\mathrm{M}$ et al (2018) An overview of genetic and hormonal control of cotton fiber development. Pak J Bot 50:433-443

Baccelli I, Lombardi L, Luti S, Bernardi R, Picciarelli P, Scala A, Pazzagli L (2014) Cerato-platanin induces resistance in Arabidopsis leaves through stomatal perception, overexpression of salicylic acid-and ethylene-signalling genes and camalexin biosynthesis. PLoS One 9(6). https://doi.org/10.1371/journal.pone. 0100959

Bajwa KS et al (2013) Expression of Calotropis procera expansin gene CpEXPA3 enhances cotton fibre strength. Aust J Crop Sci 7:206

Bajwa KS, Shahid AA, Rao AQ, Bashir A, Aftab A, Husnain T (2015) Stable transformation and expression of GhEXPA8 fiber expansin gene to improve fiber length and micronaire value in cotton. Front Plant Sci 6:838. https://doi.org/10.3389/fpls.2015.00838

Buschmann H, Holtmannspötter M, Borchers A, O'Donoghue MT, Zachgo S (2016) Microtubule dynamics of the centrosome-like polar organizers from the basal land plant Marchantia polymorpha. New Phytol 209:999-1013. https://doi.org/10.1111/nph.13691 
Cosgrove DJ (2014) Re-constructing our models of cellulose and primary cell wall assembly. Curr Opin Plant Biol 22:122-131. https://doi. org/10.1016/j.pbi.2014.11.001

Cosgrove DJ (2015a) Plant cell wall extensibility: connecting plant cell growth with cell wall structure, mechanics, and the action of wallmodifying enzymes. J Exp Bot 67:463-476. https://doi.org/10. 1093/jxb/erv511

Cosgrove DJ (2015b) Plant expansins: diversity and interactions with plant cell walls. Curr Opin Plant Biol 25:162-172. https://doi.org/ 10.1016/j.pbi.2015.05.014

Cosgrove DJ (2016) Catalysts of plant cell wall loosening. F1000Research 5. https://doi.org/10.12688/f1000research.7180.1

Cosgrove DJ (2018) Diffuse growth of plant cell walls. Plant Physiol 176: 16-27. https://doi.org/10.1104/pp.17.01541

Feng $X$ et al (2019) TaEXPB7-B, a $\beta$-expansin gene involved in lowtemperature stress and abscisic acid responses, promotes growth and cold resistance in Arabidopsis thaliana. J Plant Physiol 240:153004. https://doi.org/10.1016/j.jplph.2019.153004

Fry SC (2018) Cell wall polysaccharide composition and covalent crosslinking. Annual Plant Reviews Online:1-42. https://doi.org/ 10.1002/9781119312994.apr0430

Georgelis N, Yennawar NH, Cosgrove DJ (2012) Structural basis for entropy-driven cellulose binding by a type-A cellulose-binding module (CBM) and bacterial expansin. Proc Natl Acad Sci 109: 14830-14835. https://doi.org/10.1073/pnas.1213200109

Guo K et al (2016) Fibre elongation requires normal redox homeostasis modulated by cytosolic ascorbate peroxidase in cotton (Gossypium hirsutum). J Exp Bot 67:3289-3301. https://doi.org/10.1093/jxb/ erw146

Han X, Kim J-Y (2016) Integrating hormone-and micromolecule-mediated signaling with plasmodesmal communication. Mol Plant 9:4656. https://doi.org/10.1016/j.molp.2015.08.015

Heinze T (2015) Cellulose: structure and properties. In: Cellulose chemistry and properties: fibers, nanocelluloses and advanced materials. Springer, pp 1-52. https://doi.org/10.1007/12_2015_319

Hernandez-Gomez MC, Runavot J-L, Meulewaeter F, Knox JP (2017) Developmental features of cotton fibre middle lamellae in relation to cell adhesion and cell detachment in cultivars with distinct fibre qualities. BMC Plant Biol 17:69. https://doi.org/10.1186/s12870017-1017-3

Huang J, Chen F, Wu S, Li J, Xu W (2016) Cotton GhMYB7 is predominantly expressed in developing fibers and regulates secondary cell wall biosynthesis in transgenic Arabidopsis. Sci China Life Sci 59: 194-205. https://doi.org/10.1007/s11427-015-4991-4

Khalil HA, Bhat A, Bakar AA, Tahir PM, Zaidul I, Jawaid M (2015) Cellulosic nanocomposites from natural fibers for medical applications: a review, Handbook of polymer nanocomposites. Processing, performance and application. Springer, pp 475-511. https://doi.org/ 10.1007/978-3-642-45232-1 72

Kuluev B, Avalbaev A, Mikhaylova E, Nikonorov Y, Berezhneva Z, Chemeris A (2016) Expression profiles and hormonal regulation of tobacco expansin genes and their involvement in abiotic stress response. J Plant Physiol 206:1-12. https://doi.org/10.1016/j.jplph. 2016.09.001

Lee Y, Choi D (2005) Biochemical properties and localization of the $\beta$ Expansin OsEXPB3 in rice (Oryza sativa L.). Mol Cell (Springer Science \& Business Media BV) 20.1

Little A et al (2018) Revised phylogeny of the cellulose synthase gene superfamily: insights into cell wall evolution. Plant Physiol 177: 1124-1141. https://doi.org/10.1104/pp.17.01718

Marowa P, Ding A, Kong Y (2016) Expansins: roles in plant growth and potential applications in crop improvement. Plant Cell Rep 35:949 965. https://doi.org/10.1007/s00299-016-1948-4

McCann MC, Knox JP (2018) Plant cell wall biology: polysaccharides in architectural and developmental contexts. Annual Plant Reviews online:343-366. https://doi.org/10.1002/9781119312994.apr0443
McQueen-Mason S, Cosgrove DJ (1994) Disruption of hydrogen bonding between plant cell wall polymers by proteins that induce wall extension. Proc Natl Acad Sci 91:6574-6578. https://doi.org/10. 1073/pnas.91.14.6574

Meents MJ, Watanabe Y, Samuels AL (2018) The cell biology of secondary cell wall biosynthesis. Ann Bot 121:1107-1125. https://doi. org/10.1093/aob/mcy005

Mollet J-C, Leroux C, Dardelle F, Lehner A (2013) Cell wall composition, biosynthesis and remodeling during pollen tube growth. plants 2:107-147. https://doi.org/10.3390/plants2010107

Ortega JK (2017) Dimensionless number is central to stress relaxation and expansive growth of the cell wall. Sci Rep 7:3016. https://doi. org/10.1038/s41598-017-03002-6

Ramakrishna P et al (2019) EXPANSIN A1-mediated radial swelling of pericycle cells positions anticlinal cell divisions during lateral root initiation. Proc Natl Acad Sci 116:8597-8602. https://doi.org/10. 1073/pnas.1820882116

Ramamoorthy SK, Skrifvars M, Persson A (2015) A review of natural fibers used in biocomposites: plant, animal and regenerated cellulose fibers. Polym Rev 55:107-162. https://doi.org/10.1080/15583724. 2014.971124

Rathgeber CB, Cuny HE, Fonti P (2016) Biological basis of tree-ring formation: a crash course. Front Plant Sci 7:734. https://doi.org/10. 3389/fpls.2016.00734

Ruan Y-L (2007) Rapid cell expansion and cellulose synthesis regulated by plasmodesmata and sugar: insights from the single-celled cotton fibre. Funct Plant Biol 34:1-10. https://doi.org/10.1071/FP06234

Sampedro J, Cosgrove DJ (2005) The expansin superfamily. Genome Biol 6:242. https://doi.org/10.1186/gb-2005-6-12-242

Sampedro J, Guttman M, Li LC, Cosgrove DJ (2015) Evolutionary divergence of $\beta$-expansin structure and function in grasses parallels emergence of distinctive primary cell wall traits. Plant J 81:108-120. https://doi.org/10.1111/tpj.12715

Saxena IM, Brown RM Jr (2005) Cellulose biosynthesis: current views and evolving concepts. Ann Bot 96:9-21. https://doi.org/10.1093/ $\mathrm{aob} / \mathrm{mci} 155$

Smertenko A et al (2018) Phragmoplast microtubule dynamics-a game of zones. J Cell Sci 131:jcs203331. https://doi.org/10.1242/jcs.203331

Somssich M, Khan GA, Persson S (2016) Cell wall heterogeneity in root development of Arabidopsis. Front Plant Sci 7:1242. https://doi.org/ 10.3389/fpls.2016.01242

Stiff MR, Tuttle JR, Graham BP, Haigler CH (2016) Cotton fiber biotechnology: potential controls and transgenic improvement of elongation and cell wall thickening. In: Fiber plants. Springer, pp 127153. https://doi.org/10.1007/978-3-319-44570-0 8

Sun Y, Veerabomma S, Fokar M, Abidi N, Hequet E, Payton P, Allen RD (2015) Brassinosteroid signaling affects secondary cell wall deposition in cotton fibers. Ind Crop Prod 65:334-342. https://doi.org/10. 1016/j.indcrop.2014.11.028

Suzuki H, Oshita E, Fujimori N, Nakajima Y, Kawagoe Y, Suzuki S (2015) Grape expansins, VvEXPA14 and VvEXPA18 promote cell expansion in transgenic Arabidopsis plant plant cell. Tissue and Organ Culture (PCTOC) 120:1077-1085. https://doi.org/10.1007/ s11240-014-0662-6

Voxeur A, Höfte H (2016) Cell wall integrity signaling in plants: "to grow or not to grow that's the question". Glycobiology 26:950-960. https://doi.org/10.1093/glycob/cww029

Wang G, Gao Y, Wang J, Yang L, Song R, Li X, Shi J (2011) Overexpression of two cambium-abundant Chinese fir (Cunninghamia lanceolata) $\alpha$-expansin genes ClEXPA1 and CIEXPA2 affect growth and development in transgenic tobacco and increase the amount of cellulose in stem cell walls. Plant Biotechnol J 9:486-502. https://doi.org/10.1111/j.1467-7652.2010. 00569.x 
Wang Y et al (2014) Regulation of the $\alpha$-expansin gene OsEXPA8 expression affects root system architecture in transgenic rice plants. Mol Breed 34:47-57. https://doi.org/10.1007/s11032-014-0016-4

Williams P, Saffer A, Irish V, Shattuck M, O'Hern C (2018) Computational models of the role of pectins in plant cell wall structure 63. JBotAPS

Xi W, Song D, Sun J, Shen J, Li L (2017) Formation of wood secondary cell wall may involve two type cellulose synthase complexes in Populus. Plant Mol Biol 93:419-429. https://doi.org/10.1007/ s11103-016-0570-8

Xiao C, Zhang T, Zheng Y, Cosgrove DJ, Anderson CT (2016) Xyloglucan deficiency disrupts microtubule stability and cellulose biosynthesis in Arabidopsis, altering cell growth and morphogenesis. Plant Physiol 170:234-249. https://doi.org/10.1104/pp.15. 01395

Yang JH, Wang H (2016) Molecular mechanisms for vascular development and secondary cell wall formation. Front Plant Sci 7:356. https://doi.org/10.3389/fpls.2016.00356

Yennawar NH, Li L-C, Dudzinski DM, Tabuchi A, Cosgrove DJ (2006) Crystal structure and activities of EXPB1 (Zea m 1), a $\beta$-expansin and group-1 pollen allergen from maize. Proc Natl Acad Sci 103: 14664-14671. https://doi.org/10.1073/pnas.0605979103
Yi K, Li R (2012) Actin cytoskeleton in cell polarity and asymmetric division during mouse oocyte maturation. Cytoskeleton 69:727737. https://doi.org/10.1002/cm.21048

Zenoni S et al (2011) Overexpression of PhEXPA1 increases cell size, modifies cell wall polymer composition and affects the timing of axillary meristem development in Petunia hybrida. New Phytol 191: 662-677. https://doi.org/10.1111/j.1469-8137.2011.03726.x

Zhang T, Zheng Y, Cosgrove DJ (2016) Spatial organization of cellulose microfibrils and matrix polysaccharides in primary plant cell walls as imaged by multichannel atomic force microscopy. Plant $\mathrm{J} 85$ : 179-192. https://doi.org/10.1111/tpj.13102

ZhiMing Y et al (2011) Root hair-specific expansins modulate root hair elongation in rice. Plant J 66:725-734. https://doi.org/10.1111/j. 1365-313X.2011.04533.x

Zou H, Wenwen Y, Zang G, Kang Z, Zhang Z, Huang J, Wang G (2015) OsEXPB2, a $\beta$-expansin gene, is involved in rice root system architecture. Mol Breed 35:41. https://doi.org/10.1007/s11032-0150203-y

Publisher's note Springer Nature remains neutral with regard to jurisdictional claims in published maps and institutional affiliations. 